\title{
Lazer Baskılı Ofis Kâğıtları Üzerinde Yapılan Mürekkep Giderme İşleminin Süzüntü Suyu Üzerine Etkileri
}

\section{The Effects on Waste Water of Deinking Process Made on Laser Printed Office Papers}

\author{
Selim KARAHAN ${ }^{* 1, a}$, Arif KARADEMIR ${ }^{2, b}$ \\ ${ }^{1}$ Gümüşhane Üniversitesi Kürtün MYO, Ormancllk Bölümü, 29810 Kürtün-Gümüşhane \\ ${ }^{2}$ Bursa Teknik Üniversitesi, Orman Fakültesi, Orman Endüstri Mühendisliği Bölümü, Osmangazi-Bursa
}

• Geliş tarihi / Received: 18.08.2019 • • Düzeltilerek geliş tarihi / Received in revised form:28.01.2020 • Kabul tarihi / Accepted: 02.02.2020

\begin{abstract}
Öz
Çalışmada, önce lazer baskı uygulanmış beyaz A4 ofis kâğıtları üzerinde hamurlaştırma işlemleri uygulanmıştır. Daha sonra ise hamurlaştırılan ofis kâğıtları üzerinde belirlenmiş oranlarda karışımlar hazırlanmıştır. Bu hamurlaştırma ve karışım hazırlama sürecinde ise farklı yüzde oranlarda kimyasal ve enzimden faydalanılmıştır. Kimyasal madde olarak oleik asit, sodyum hidroksit, sodyum silikat, kalsiyum klorür ve hidrojen peroksit kullanılmıs ve enzim olarak ise selülaz, ksilanaz, amilaz ve $\beta$-gluktonaz kullanılmıştır. Çalışmada daha sonra ultrases etkisine bakılmıştır. En sonunda ise hamur süspansiyonu yüzdürme yöntemi ile mürekkeplerinden uzaklaştırılması yapılmıştır. Tüm bu işlemler sonunda ise atık su analizleri yapılmıştır.
\end{abstract}

Anahtar kelimeler: Atık Su, Enzimler, Lazer Baskı, Mürekkep Giderme, Ultrasonik İşlem

\begin{abstract}
In this study, first of all, pulping processes were applied on white A4 office paper which was applied laser printing. Then, mixtures were prepared in the proportions determined on the pulped office papers. In this pulping and mixture preparation process, different ratios of chemicals and enzymes were utilized. As chemical substances, oleic acid, sodium hydroxide, sodium silicate, calcium chloride and hydrogen peroxide were used and cellulase, xylanase, amylase and $\beta$-gluconase were used as enzyme. Then, ultrasound effect was examined. Finally, the pulp suspension was removed from the inks by flotation. At the end of all these processes, wastewater analysis was performed.
\end{abstract}

Keywords: Waste Water, Enzymes, Laser Printing, Deinking, Ultrasonic Treatment

\footnotetext{
*a Selim KARAHAN; selimkarahan @msn.com; Tel: (0456) 2331018 (dahili: 3402); orcid.org/0000-0002-8499-2427

${ }^{\mathrm{b}}$ orcid.org/0000-0003-0924-2156
} 


\section{Giriş}

Ülkemizde kâğıt ve karton tüketimi günden güne çoğalmaktadır. Hammadde tedariki için geri dönüşümün önemi çoktur. Bunun için atık kâğıtların dönüştürülerek yeniden kâğıt sektöründe lifsel hammadde kaynağ 1 olarak kullanılma imkânları incelenmelidir (Karahan vd., 2015a; Karahan, 2017a).

Kâğıt sektörü, diğer sektörler içerisinde enzim kullanabilen pazarların en büyüğü olarak kabul görmüştür. Kâğıt endüstrisinde enzim kullanımının gerekçeleri arasında hamur verimi ve lif özelliklerinin iyileştirilmesi ve enerji ile birlikte su tüketiminin düşürülmesi gibi konular yer almaktadır. Son dönemlerde kâğıt sektöründe enzimlerin kullanılabilmesi adına yapilan çalışmalar hızlanmıştır (Karademir vd., 2002a; Karahan vd., 2015a).

Enzim sektöründeki gelişmeler ile kağıt mamullerin farklı farklı yerlerde kullanılması ve maliyetinin fazla olması dolayısıyla endüstriyel enzimler ile ilgili araştırmalarda hızlanmıştır (Kiran vd., 2006; Karahan vd., 2015a). Enzim uygulamaları dikkat gerektirdiği için her bir aşamanın kontrolüne önem verilmelidir (Karademir vd., 2002b; Karahan, 2017b). Enzim uygulamasiyla liflerdeki toner lekeleri uzaklaştırılır. Enzimler mürekkep-selüloz bağını kırabildikleri için toner lekelerinin liflerden çıkarılması kimyasallara göre daha basittir (Y1lgör vd., 2009; Karahan vd., 2015b). Mürekkep giderme işlemlerinde kimyasal kullanımının yerini enzim alması durumunda bu işlemde daha ekonomik olacaktır (Y1lgör, 2010; Karahan vd., 2015a).

Kâğıt sektörü gibi sektörlerde yeni teknolojilere yatırım yapmak oldukça maliyetli olmaktadır. Oysaki enzim teknoloji ile benzeri olan teknolojileri daha uyguna yapılabilir (Kenealy, vd., 2006; Karahan ve Karademir, 2019). Enzimatik uygulamaların çevre açısından yararlı olduğu ve mürekkep giderme işlemlerinde kullanılan kimyasal maddelere de iyi bir seçenek olacaktır. Diğer yandan mürekkep giderme işlemlerinde selüloz uygulaması ile bu işlem için kullanılan kimyasal miktarında düşüş görülmüştür (Skals vd., 2008; Karahan, 2017b; Karahan, 2017c; Karahan vd., 2015b). Enzim konusunda yapılan fabrika çalışmalarının umut verici sonuçlara ulaşılmıştır (Karademir vd., 2002a). Kâğıt sektöründe mürekkep giderme işlemlerinde enzim uygulamasının hem maddi hem de doğaya faydası bakımından daha yararlı olacağı düşünülmektedir (Y1lgör, 2010; Karahan vd., 2015a).

Ultrasonik işlem ile fazla sayıda malzeme cihaz vasitasiyla tutulur (Brodeur ve Gerhardstein, 1998; Karahan, 2017c; Karahan vd., 2015a). Araştırmada ofis kâğıtları üzerinde ultrasonun etkisine de bakılmıştır. Çalışmada utrason işlemi yüzdürme ile mürekkep gidermeden önce hamurlaştırılmış lif süspansiyonuna yapılmıştır. Yapılan bu işlem sonucunda lif de hem hacim olarak büyüme hem de esnekliğine sebep olmuştur. Lifler üzerine uygulanan dövme işlemi akabinde yapılan ultrasonik muamele ile liflerin su tutma değerleri de iyileşmiştir (Tatsumi vd., 2000; Karahan, 2017c; Karahan vd., 2015a).

\section{Deneysel Çalışma}

\subsection{Materyal}

Araştırmada öncelikle baskılı beyaz A4 ofis kâğıtları hamurlaştırılıp sonrasında ise mürekkep uzaklaştırma işlemleri uygulanmıştır. Mürekkep uzaklaştırmada standart yüzdürme yöntemi uygulanmıştır. Çalışmada ayrıca ultrasonik işlemde denenmiştir. İşlemler sırasında birtakım kimyasallar ve enzimlerden de faydalanılmıştır. Öncelikle atık ofis kâğıtları belli şartlar altında hamurlaştırılıp sonrasında ise belirlen oranlarda enzim ile muamele görmüştür. İşlem sonrasında ise süspansiyona kimyasal katkısı yapılarak ikinci hamurlaştırma işlemine alınmıştır. $\mathrm{Bu}$ işlemin sonucunda hamur süspansiyonu belli şartlar altında ultrasonik işlem uygulaması denenmiştir. Ultrasonik işlem sonrasında işlem görmüş olan hamuru süspansiyonu, yüzdürme esaslı mürekkep uzaklaştırma işlemi uygulanmıştır. Tüm bu işlemlerin sonunda ise at $1 \mathrm{k}$ su analizleri yapılmıştır (Karahan, 2017b). Araştırmada selülaz, ksilanaz, amilaz ve $\beta$-gluktonaz enzimleri ile ayrica oleik asit, sodyum hidroksit, sodyum silikat, kalsiyum klorür ve hidrojen peroksit gibi kimyasallarda ingede (2007) yöntemine göre alınmıştır (Karahan, 2017c). İşlem sonrası atıl sudan alınan numuneler de toplam çözünmüş katı madde (TDS) miktarları Hanna marka cihaz ile kaydedilmiştir (Şekil 1). Askıda katı madde miktarı tayininde ise buhner hunisinden faydalanılmıştır (Şekil 2).

\subsection{Metot}

Çalışmada bazik kâğıt olarak kullanılan A4 ebatlarındaki ofis kâğıtları 1S1 ve nem dengesinin sağlanması amaciyla $20 \pm 1{ }^{0} \mathrm{C}$ ve $\% 50 \pm 2$ bağ 1 nemde bekletilmiştir. 


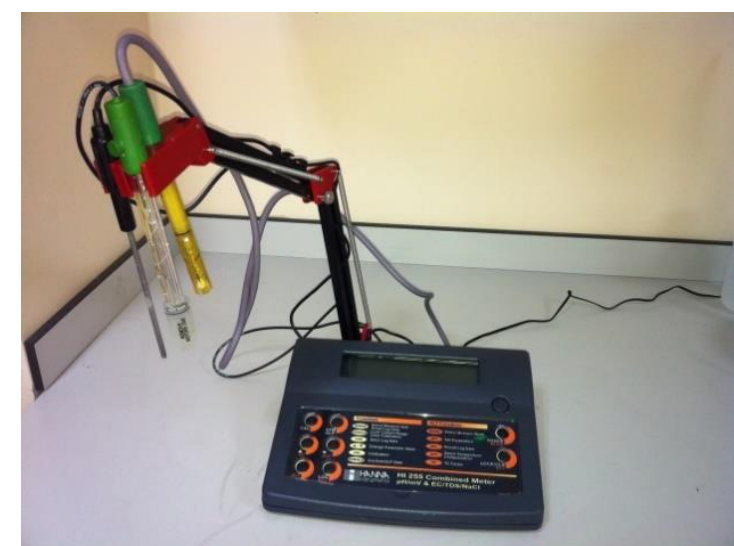

Şekil 1. Süzüntü suyu ölçüm cihazı

Sonrasında ise baskı yapılıp aynı ortam şartlarında yeniden bekletilmiştir. Baskılı ofis kâğıtlarına iki aşamada hamur süspansiyonu haline getirilmiştir. Her aşamada $103.11 \mathrm{~g}$ (Tam kuru) hamur süspansiyonundan yararlanılmıştır. Hamuru süspansiyon haline getirmek için Hobart tipi cihazdan faydalanılmıştır. Bu cihaz ile bulunan veriler tablo 1'de gösterilmiştir (Karahan ve Karademir, 2019). Birinci hamurlaştırma işleminden sonra sırasıyla enzim uygulaması, ultrasonik uygulaması ve mürekkep giderme işlemleri yapılmıştır. Ultrasonik işlemde, ultrases $24000 \mathrm{~Hz}$ ve kesafet \% 1 olarak ayarlanmıştır.

Araştırmada selülaz, ksilanaz, amilaz ve $\beta$ gluktonaz enzimlerindan faydalanılmıştır. Liflerden hemiselülazı çözebilmek için $\beta$ gluktonaz ve ksilanaz, yüzey yapıştırmada kullanılan nişastayı çözebilmesi için selüloz ve amilaz enzimleri, mürekkebi liften çözebilmek

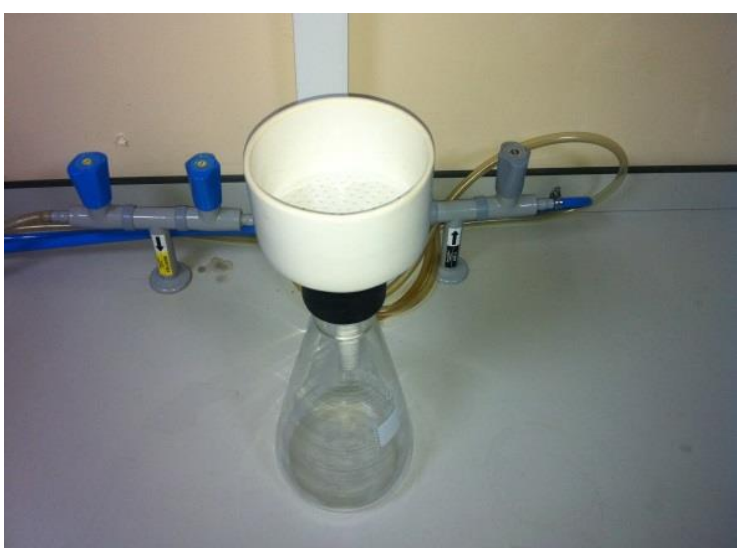

Şekil 2. Buhner hunisi

içinde selülaz enziminden faydalanılmıştır. Tablo 2 'de selülaz, ksilanaz, amilaz ve $\beta$-gluktonaz enzimleri için çalışma koşulları verilmiştir. Süzüntü su ile ilgili analiz işlemlerin de sırasıyla, askıda katı madde miktarı (AKM), toplam çözünmüş katı madde (TDS), kimyasal oksijen isteği (KOİ) ve biyolojik oksijen isteği (BOI) ile ilgili veriler ölçülmüştür.

Araştırmada belirtilen;

TDS: Toplam çözünmüş katı madde miktarı. AKM: Askıda kalan katı madde miktarı.

BOİ: Sudaki organik materyallerin mikroorganizmalar tarafindan parçalanabilmesi için gerekli miktardaki oksijen miktarıdır. BOİ değeri ne kadar çok ise suda o ölçüde su kirlidir.

KOİ: Su ve atık su numunelerinde kirlilik ölçüm parametresidir.

Tablo 1. Hamurlaştırma ile ilgili değerler (Karahan, 2012).

\begin{tabular}{cccccc}
\hline İşlem & $\begin{array}{c}\text { Devir } \\
\text { Devir /dk }\end{array}$ & $\begin{array}{c}\text { Kesafet } \\
\mathbf{\%}\end{array}$ & $\begin{array}{c}\text { Süre } \\
\mathbf{d k}\end{array}$ & $\begin{array}{c}\text { Kâğıt \& Hamur } \\
\text { Miktarı } \\
\mathbf{g}\end{array}$ & $\begin{array}{c}\text { Kimyasal } \\
\text { Madde }\end{array}$ \\
\hline Ön bekletme (Islatma) & --- & 15 & 5 & 103.11 & - \\
\hline 1. Hamurlaştırma & $55-85-150$ & 15 & $9(3-3-3)$ & 103.11 & + \\
\hline 2. Hamurlaştırma & 150 & 14 & 9 & 103.11 & - \\
\hline
\end{tabular}

Tablo 2. Selülaz, Ksilanaz, Amilaz ve $\beta$-Gluktonaz enzimleri için çalışma koşulları (Karahan, 2012).

\begin{tabular}{ccccc}
\hline Enzimler & $\begin{array}{c}\text { Dozaj } \\
\mathbf{k g} / \mathbf{t o n}\end{array}$ & $\mathbf{p H}$ & $\begin{array}{c}\text { Süre } \\
\mathbf{d k}\end{array}$ & $\begin{array}{c}\text { Sicaklık } \\
{ }^{\mathbf{0}} \mathbf{C}\end{array}$ \\
\hline Ksilanaz & $0.5-1$ & $5-7$ & 60 & 45 \\
\hline B-Gluktonaz & $0.04-0.06$ & $4-5$ & 60 & 70 \\
\hline Amilaz & $10-20$ & $7-8$ & 60 & 50 \\
\hline Selülaz & $5-20$ & $7-8$ & 60 & 50 \\
\hline
\end{tabular}




\section{Bulgular ve Tartışma}

Atık suya ait değerler şekillerde gösterilmiştir (Bkz. Şekil 3-12).

Enzimlerin en yüksek TDS değerlerine bakıldığında (Şekil 3), ksilanaz ( $\%$ 0.1), $\beta$ - gluktonaz ( $\%$ 0.01), amilaz (\% 1) ve selülaz (\% 0.5 ) için sırasılya $168 \mathrm{mg} / \mathrm{l} ; 164 \mathrm{mg} / \mathrm{l} ; 165 \mathrm{mg} / \mathrm{l} \mathrm{ve}$ $163 \mathrm{mg} / \mathrm{l}$ olarak bulunmuştur. Bu enzimlere ait en düşük TDS değerlerine bakıldığında ise ksilanaz (\% 0.4), $\beta$ - gluktonaz (\% 0.0025), amilaz (\% 4) ve selülaz (\% 2) için sırasıyla $150 \mathrm{mg} / 1 ; 158 \mathrm{mg} / \mathrm{l}$; $148 \mathrm{mg} / \mathrm{l}$ ve $150 \mathrm{mg} / \mathrm{l}$ olarak bulunmuştur.

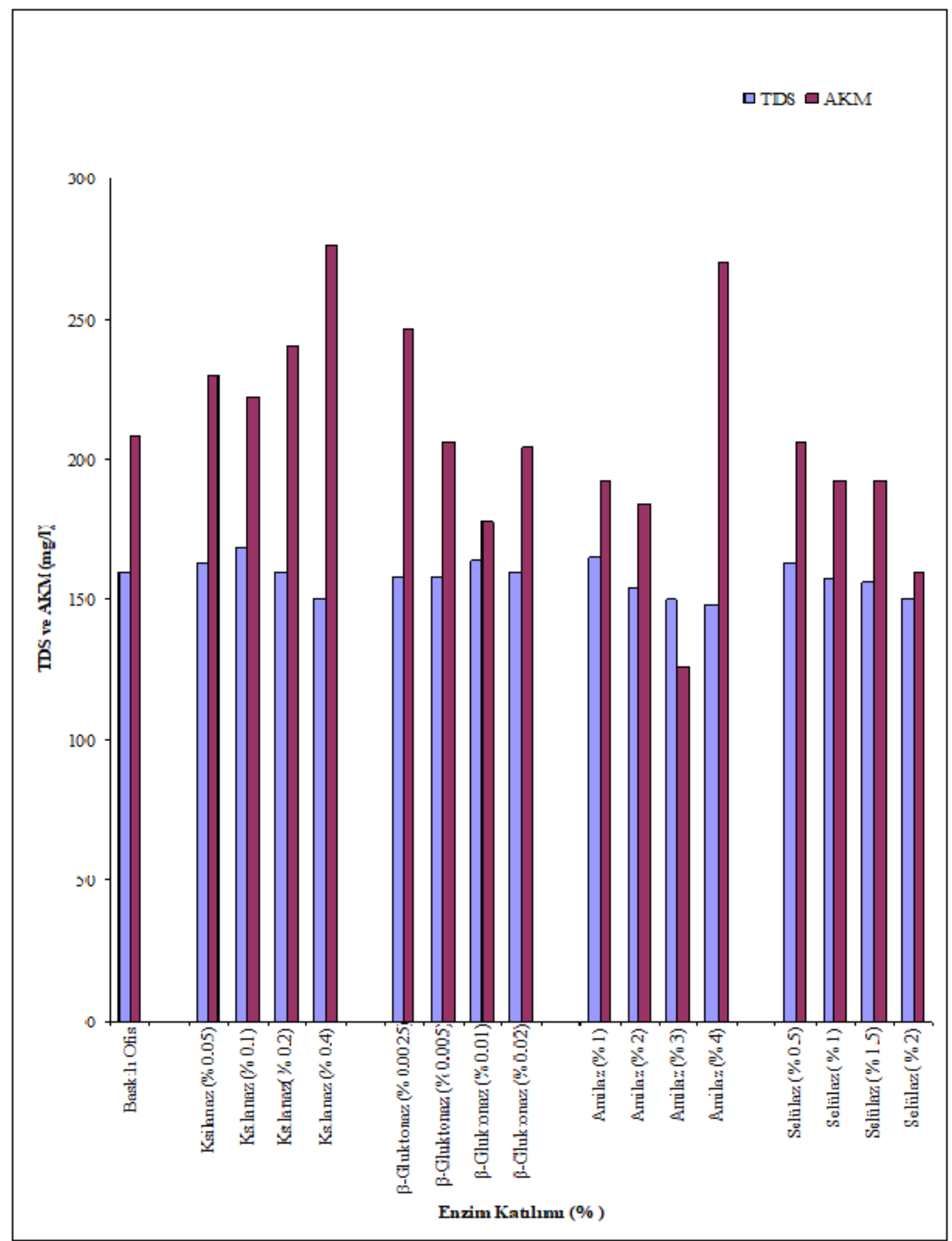

Şekil 3. Ksilanaz, $\beta$ - Gluktonaz, Amilaz ve Selülaz eklenmesinin belirli miktarlarda çoğaltılmasının TDS ve AKM üzerindeki etkileri 
Şekil 3' te verilen enzimlerin en yüksek AKM değerlerine bakıldığında ksilanaz (\% 0.4$), \quad \beta-$ gluktonaz (\% 0.0025), amilaz (\% 4) ve selülaz (\% $0.5)$ için sırasıyla $276 \mathrm{mg} / \mathrm{l} ; 246 \mathrm{mg} / 1 ; 270 \mathrm{mg} / \mathrm{l}$ ve $206 \mathrm{mg} / \mathrm{l}$ olarak bulunmuştur. Bu enzimlere ait en düşük $\mathrm{AKM}$ değerleri ise ksilanaz (\% 0.1), $\beta$ gluktonaz (\% 0.01), amilaz (\% 3) ve selülaz (\% 2) için sırasıyla $222 \mathrm{mg} / \mathrm{l} ; 178 \mathrm{mg} / \mathrm{l} ; 126 \mathrm{mg} / \mathrm{l}$ ve 160 $\mathrm{mg} / \mathrm{l}$ olarak bulunmuştur.

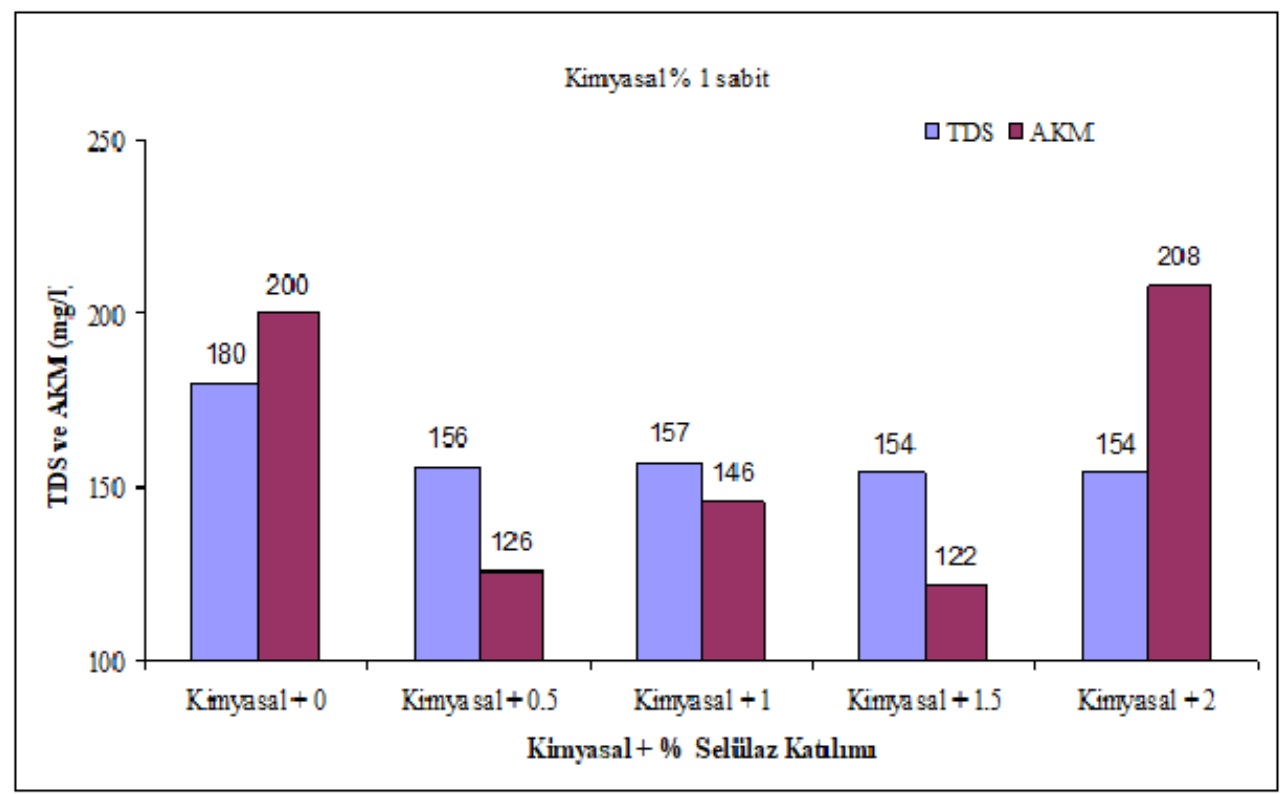

Şekil 4. Kimyasal eklenmesi sabit tutulurken Selülaz eklenmesinin belirli miktarlarda çoğaltılmasının $(\% 0.5 ; 1 ; 1.5 ; 2)$ TDS ve AKM üzerindeki etkileri

Şekil 4'e bakıldığında, TDS miktarında fazla bir değişiklik olmazken AKM miktarında ise selülazın kimyasalsız işlemine göre biraz düşüş yaşanmıştır. TDS için en iyi değer kimyasal \% $1+$ selülaz \% 0.5 olurken, AKM için en iyi değerler ise $156 \mathrm{mg} / \mathrm{l}$ ve $106 \mathrm{mg} / \mathrm{l}$ elde edilmiştir (Karahan, 2012).

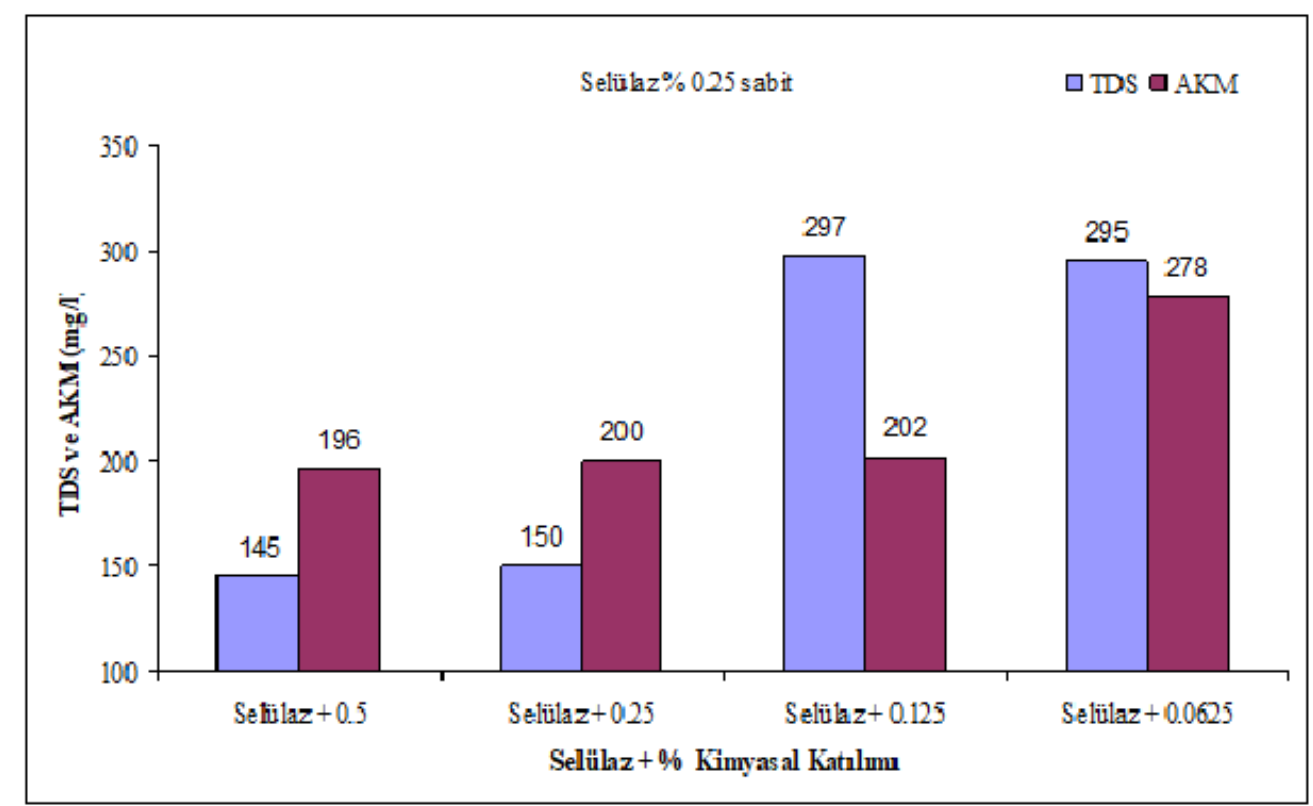

Şekil 5. Selülaz eklenmesi sabit tutulurken kimyasal eklenmesinin belirli miktarlarda düşürülmesinin $(\% 0.5 ; 0.25 ; 0.125 ; 0.0625)$ TDS ve AKM üzerindeki etkileri 
Şekil 5'e bakıldığında, TDS ve AKM miktarlarında genel bir artış gözlemlenmiştir. Muhtemelen bu birlikte kullanım hamurdaki çözünme miktarını artırmıştır. TDS için en iyi değer selülaz \% 0.25 + kimyasal \% 0.125 olurken, AKM için en iyi değerler ise $311 \mathrm{mg} / \mathrm{l}$ ve 202 $\mathrm{mg} / \mathrm{l}$ elde edilmiştir.

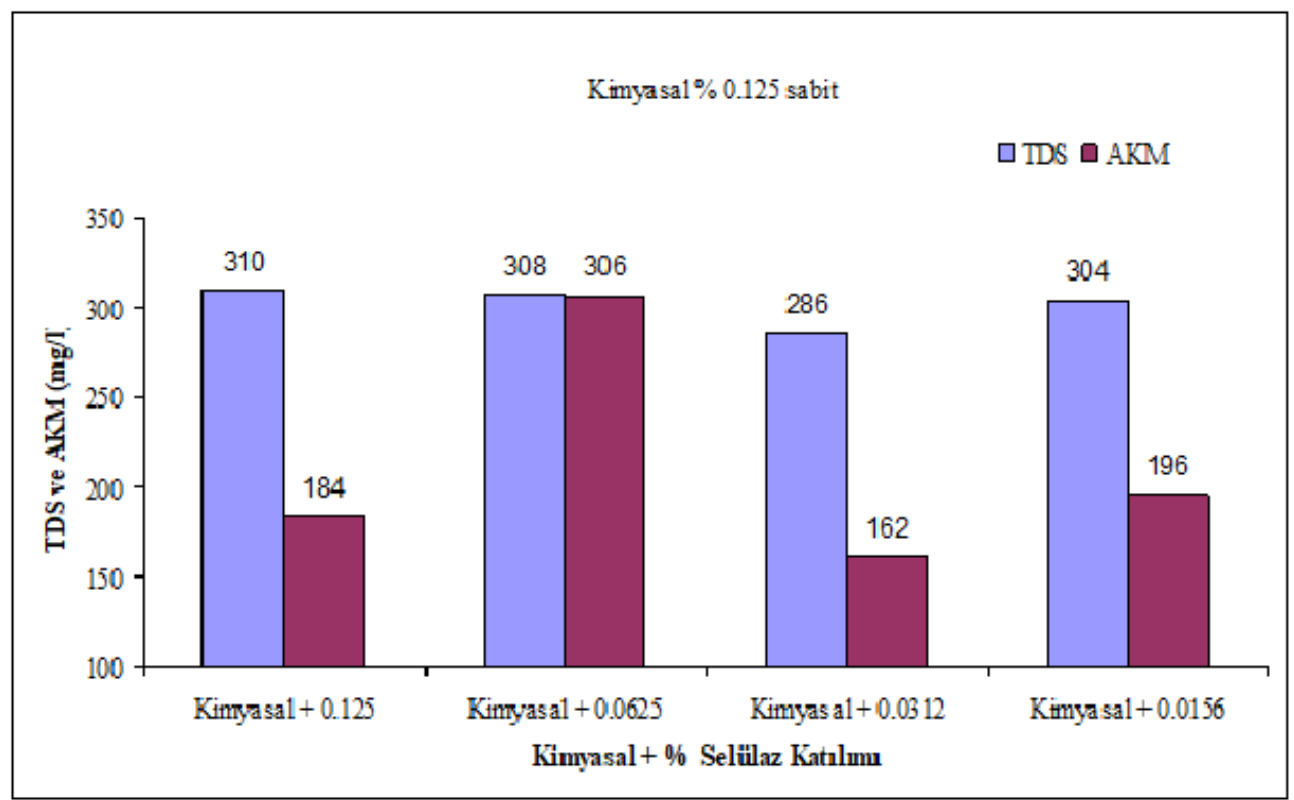

Şekil 6. Kimyasal eklenmesi \% 0.125 sabit tutulurken Selülaz eklenmesinin belirli miktarlarda düşürülmesinin $(\% 0.125 ; 0.0625 ; 0.0312 ; 0.0156)$ TDS ve AKM üzerindeki etkileri

Şekil 6'ya bakıldığında, TDS miktarlarında genel bir artış yaşanmıştır. AKM ise selülazın \% 0.0625 katılımı hariç genel bir azalış yaşanmıştır. Bu durum muhtemelen kırıntı olan selülazın flotasyon çamuruna tutunduğu düşünülebilir. TDS için en iyi değer kimyasal \% 0.125 +selülaz \% 0.0312 olurken, AKM için en iyi değerler ise $311 \mathrm{mg} / 1$ ve $202 \mathrm{mg} / \mathrm{l}$ elde edilmiştir.

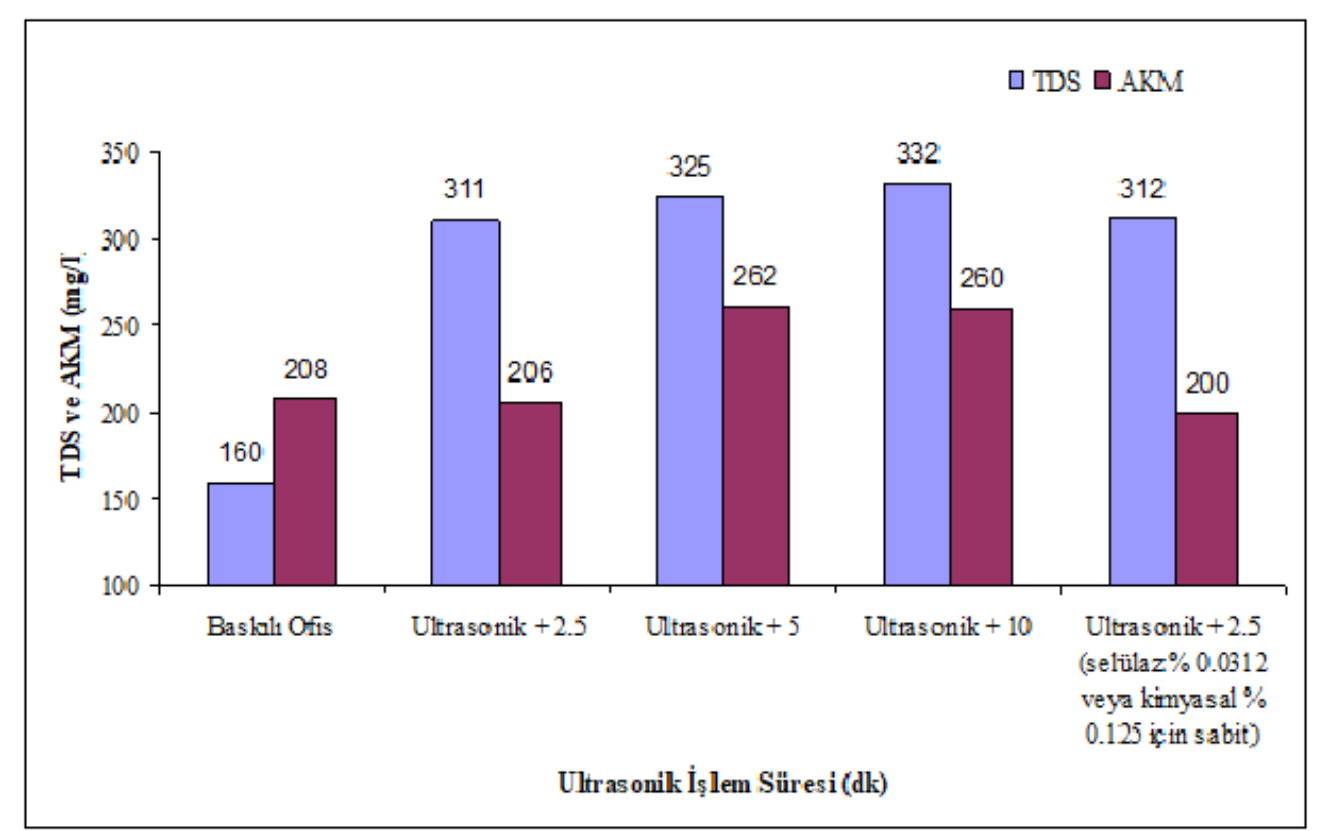

Şekil 7. Ultrasonik uygulama zamanının (dk $0 ; 2.5 ; 5 ; 10)$ TDS ve AKM üzerindeki etkileri 
Şekil 7'ye bakıldığında, TDS ve AKM en fazla artış yaşandığı gözlemlenmiştir. Muhtemelen bu durum ultrasonik işlemin kırıntı miktarını artırması olarak söylenebilir. TDS için en iyi değer kimyasal \% $0.125+$ selülaz $\% 0.0312$ ve AKM için en iyi değerler $286 \mathrm{mg} / \mathrm{l}$ ve $162 \mathrm{mg} / \mathrm{l}$ olurken, $2.5 \mathrm{dk}$. Ultrasonik uygulaması ardından bu değerler $312 \mathrm{mg} / \mathrm{l}$ ve $200 \mathrm{mg} / \mathrm{l}$ olarak bulunmuştur. Şekil 8'e bakıldığında, BOİ ve KOİ değerlerinin tüm enzimler için paralel çıktığı söylenebilir.

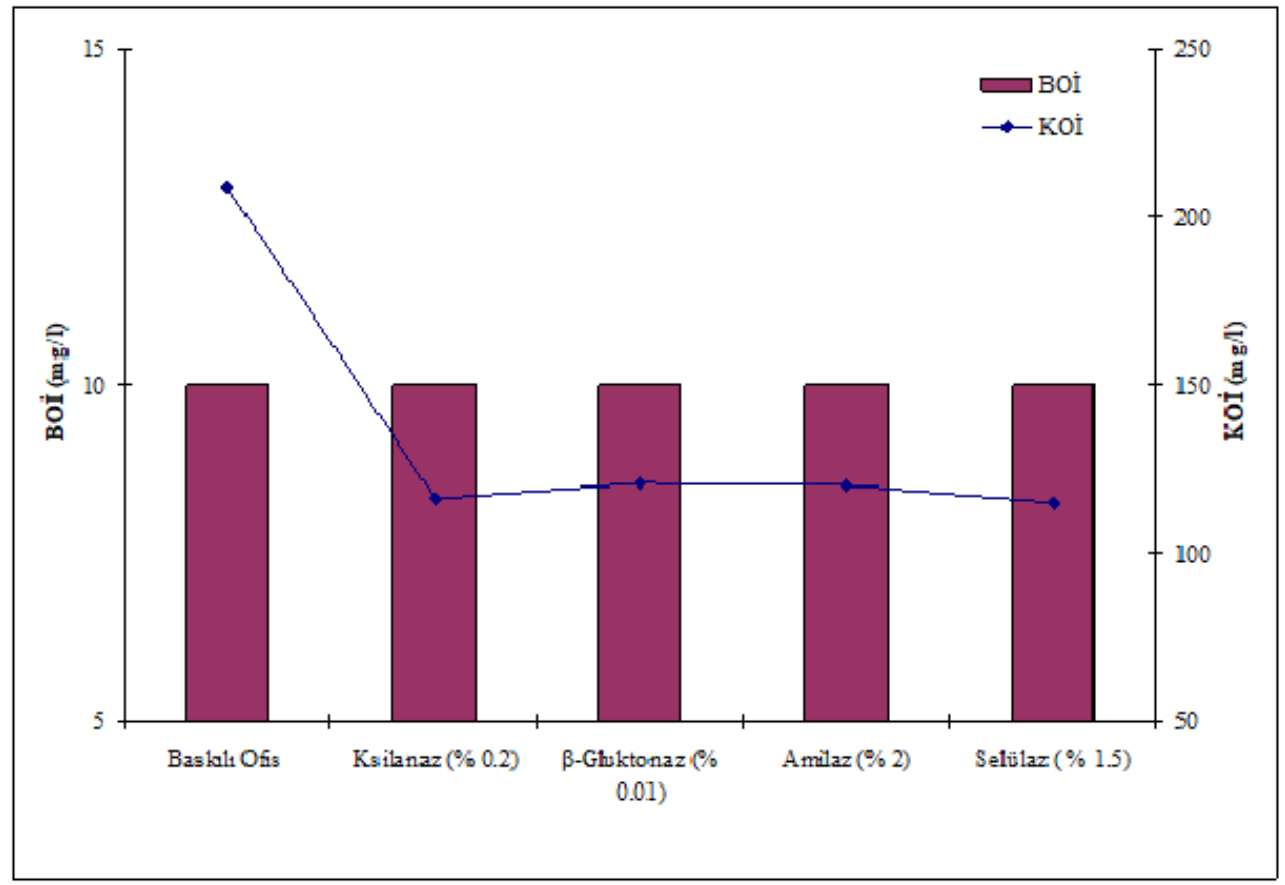

Şekil 8. Belli miktarlarda Ksilanaz, $\beta$ - Gluktonaz, Amilaz ve Selülaz eklenmesinin BOİ ve KOİ üzerindeki etkileri

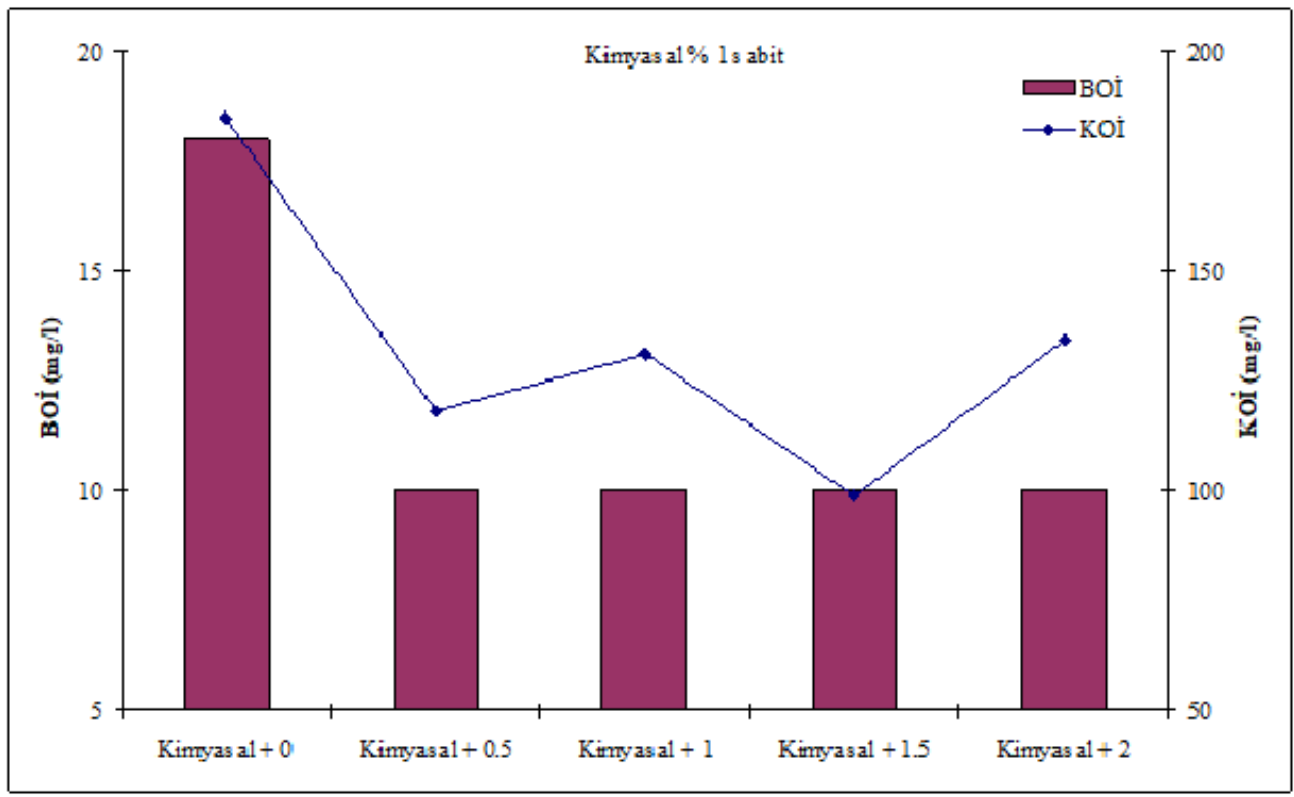

Şekil 9. Kimyasal eklenmesi sabit tutulurken Selülaz eklenmesinin belirli miktarlarda çoğaltılmasının $(\% 0.5 ; 1 ; 1.5 ; 2)$ BOİ ve KOİ üzerindeki etkileri

Şekil 9' a bakıldığında, BOİ değerleri sabit kalırken KOİ değerlerinde selülazın \% 1.5 katılımı hariç yüksek bir değer çıtı̆̆ görülmüştür. Muhtemelen Flotasyon çamurundaki kirlilik oranının yüksek oluşu bu duruma sebep olarak gösterilebilir. BOİ için en iyi değer kimyasal $\% 1+$ selülaz $\% 0.5$ olurken KOİ için en iyi değerler ise $10 \mathrm{mg} / \mathrm{l}$ ve $118 \mathrm{mg} / \mathrm{l}$ elde edilmiştir. 


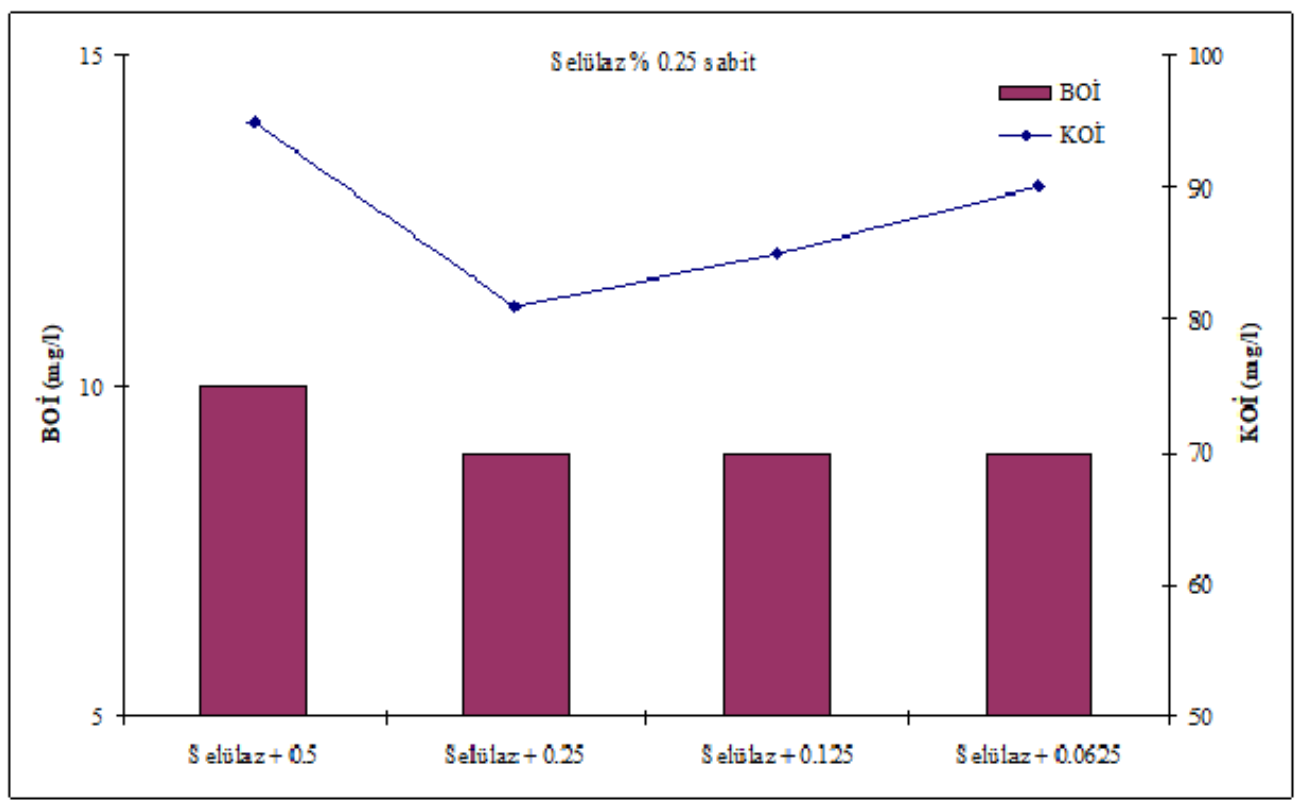

Şekil 10. Selülaz eklenmesi \% 0.25 sabit tutulurken kimyasal eklenmesinin belirli miktarlarda düşürülmesinin $(\% 0.5 ; 0.25 ; 0.125 ; 0.0625)$ BOİ ve KOİ üzerindeki etkileri

Şekil 10'a bakıldığında, BOİ ve KOİ değerlerinin selülazın tüm katılımları için parelel çıktığı söylenebilir. BOİ için en iyi değer selülaz \% 0.25
+ kimyasal \% 0.125 olurken, KOİ için en iyi değerler ise $9 \mathrm{mg} / \mathrm{l}$ ve $85 \mathrm{mg} / \mathrm{l}$ elde edilmiştir.

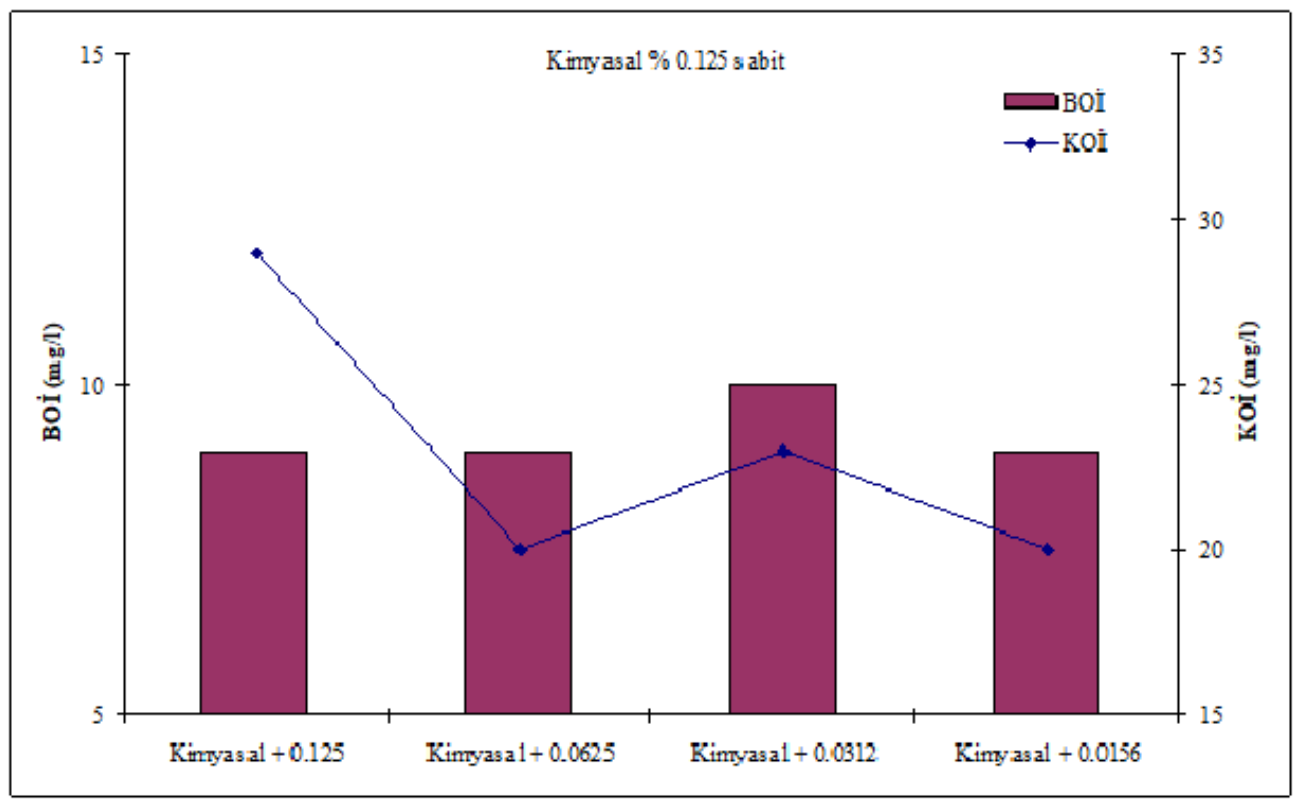

Şekil 11. Kimyasal eklenmesi sabit tutulurken Selülaz eklenmesinin belirli miktarlarda düşürülmesinin $(\% 0.125 ; 0.0625 ; 0.0312 ; 0.0156)$ BOİ ve KOİ üzerindeki etkileri

Şekil 11'e bakıldığında, BOİ ve KOİ verileri selülazın tüm eklenmelerinde parelel olduğu ve diğer eklenmelere kıyasla daha az olduğu ifade edilebilir. BOİ için en iyi değer kimyasal \% 0.125 + selülaz \% 0.0312 olurken, KOİ için en iyi değerler ise $10 \mathrm{mg} / 1$ ve $23 \mathrm{mg} / 1$ elde edilmiştir.
Şekil 12'ye bakıldığında, BOİ ve KOİ değerleri birbirine paralel seyretmektedir. Fakat ultrasonik uygulama zamanının artması ile artış olmuştur. $\mathrm{Bu}$ olay tonerin daha küçük parçalara ayrılıp atık suya geçmesi şeklinde ifade edilebilir. 


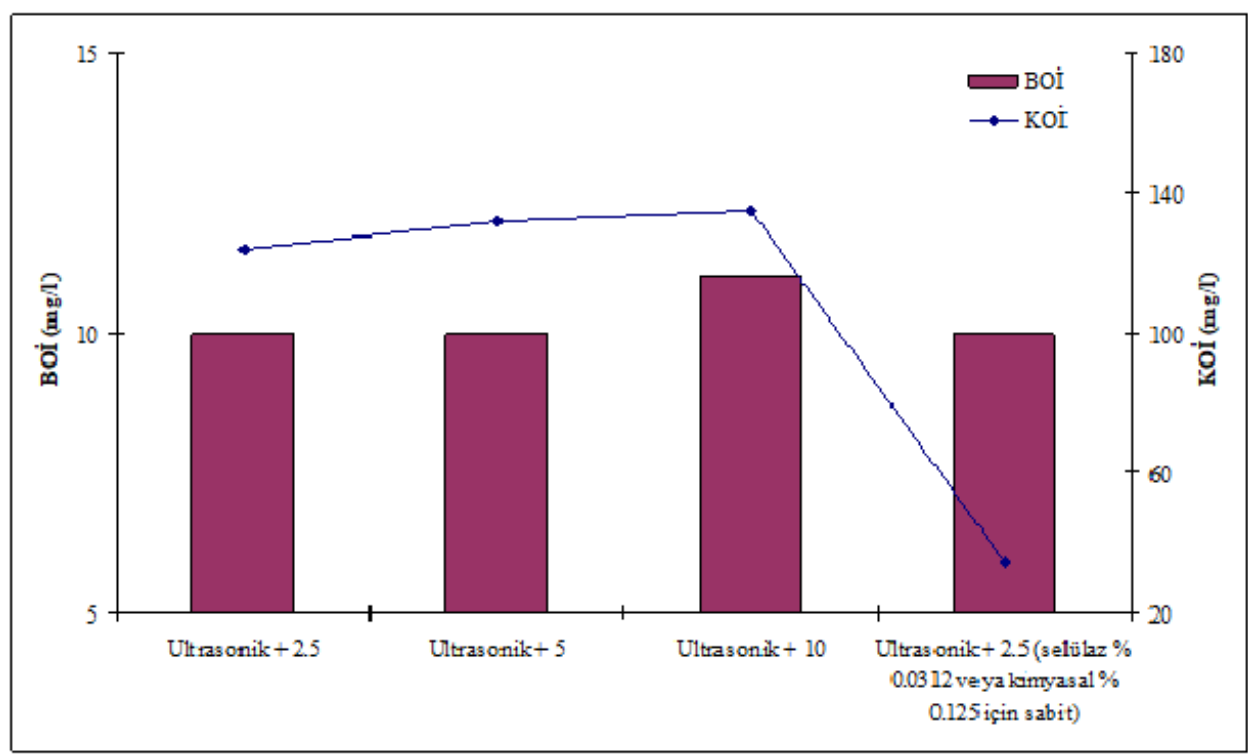

Şekil 12. Ultrasonik uygulama zamanının $(\mathrm{dk} 2.5 ; 5 ; 10)$ BOİ ve KOİ üzerindeki etkileri

Kimyasal \% $0.125+$ selülaz \% 0.0312 değere 2.5 $\mathrm{dk}$ Ultrasonik işlem ile BOİ ve KOİ verileri ise 10 $\mathrm{mg} / \mathrm{l}$ ve $34 \mathrm{mg} / \mathrm{l}$ gözlemlenmiştir.

Enzimlerin mürekkep gidermede kullanılması ile bu amaçla kullanılan kimyasal kullanımını önemli ölçüde azalttığ 1 için bu işlemlerin çevrede oluşturacağ1 kirlik endişelerini de ortadan kaldırmaktadır (Yılgör, 2010; Karahan vd., 2015b). Mürekkep gidermeye enzim kullanımının olumlu katkısından dolayı kullanılan enzim çeşitlerinin geleneksel mürekkep uzaklaştırma işlemine alternatif olacağı tahmin edilmektedir (İmamoğlu, 2002; Karahan, 2017b). Ofis kâğıtlarının yüzdürme esaslı mürekkep giderme işlemlerinde ortalama hamur verimleri $\% 81.50$ sonucuna varılmıştır (İmamoğlu, 2002; Karahan ve Karademir, 2019). Magazin dergileri ve atık kâğıtları üzerinde yüzdürme esaslı mürekkep uzaklaştırma işleminde ortalama hamur verimleri \% 80 elde edilmiştir (Peşman, 2010; Karahan vd., 2015a). Hamurlaştırma işleminin tekrarında hem hamurun daha koyulaştığı hemde hamurdaki kırıntının arttığı görülmüştür (Brodeur ve Gerhardstein, 1998). Enzim uygulamas1 ile hem kimyasal miktarında azalma görülmüş hemde süzüntü suyu kontrol altına alınmıştır (Bajpai ve Bajpai, 1998). Ultrasonik işlem suyun akışkanlığını artırmaktadır (Brodeur ve Gerhardstein, 1998). Baz kâğıtlara ait KOİ verileri ortalama $160 \quad \mathrm{mg} / \mathrm{L}$ olarak bulunmuştur (İmamoğlu, 2002).

\section{Sonuçlar}

Çalışmada TDS miktarları bütün enzimlerde kayda değer bir farklılık oluşturmazken, AKM miktarları ise hamur verimlerine göre bir parelellik seyretmektedir. Ultrasonik uygulamanın TDS ve AKM bir artış farkedilmiştir. Bu sonuçla birlikte ultrasonik uygulama ile kırınt1 miktarındada doğru orantılı olarak artığı ifade edilebilir. Belirli miktarlarda enzim eklenmesinin BOİ ve KOİ üzerindeki etkisi ise, BOİ ve KOİ verilerinin bütün enzimler de parelel olduğu ifade edilebilir. Yine benzer şekilde, ultrasonik uygulamanın zamanının BOİ ve KOİ üzerindeki etkisi ise, BOİ ve KOİ verilerinin bütün enzimler de parelel olduğu ifade edilebilir. BOİ ve KOİ değerleri birbirine parelel seyretmektedir. Bunun yanı sıra ultrasonik uygulama zamanın artması ile hamur miktarında azda olsa bir artışa neden olmaktadır. Bu durum ise ultrasonik uygulamanın zamanının artması ile birlikte toner daha fazla fiziksel mukavemet etkisinde kalıp daha da küçük parçalara ayrılmasına sebep olacaktır. $\mathrm{Bu}$ ise kırıntı tonerin hamura geçmesine sebebiyet verecektir.

Sonuçlara bakıldığında ultrasonik ve enzim uygulaması ile iyi sonuçlar alınmıştır, çalışmanın ayrica hem maddi hem de doğaya faydası bakımından olumlu sonuçları olduğu söylenebilir. Genelde varilan hususlar maddeler halinde verilmiştir (Karahan, 2012; Karahan, 2017b).

- İNGEDE standardında belirtilen kimyasal miktarı düşürülmüştür $(1 / 8)$

- Selülaz enzimi diğer enzimlere göre daha iyi değerler elde edilmiştir.

- Kimyasal ve enzimin birlikte kullanılmasinda olumlu olmuştur.

- Ultrasonik işlem başarılı sonuçlar vermiştir. 
- Enzim, kimyasal ve ultrasonik işlem atık su değerlerini iyileştirmektedir.

- Enzimler kimyasallarla uyumludur.

- Enzimler için, sıcaklık, dozaj katılımı ve ph değişken olan unsurlardandır.

- Enzimler için uygulama zamanı fazladır. Bu yüzden daha az uygulama yapılmaktadır.

- Ultrasonik işlem ile toner parçalandığı için, liflerden ayırma kolaydır.

- Ultrasonik işlemin başarısı için suyun derecesi önemlidir.

- Ultrasonik işlem ile mürekkep parçacıkları daha da ufalandığı için işlem görmüş olan hamura geçme olasılığı vardır.

\section{Teşekkür}

$\mathrm{Bu}$ çalışma Kahramanmaraş Sütçü İmam Üniversitesi Bilimsel Araştırma Projeleri Yönetim Birimi (BAP) tarafından desteklenmiştir (Proje No: 2011/3-44D). Ayrıca bu çalışma Selim Karahan tarafindan 2012 yılinda yapılan doktora tezinin'de bir bölümünü içermektedir.

\section{Kaynaklar}

Bajpai, P.and Bajpai, P.K., 1998. Deinking with Enzymes. A Review: TAPPI Journal, 81 (12), 111-117.

Brodeur, P.H. and Gerhardstein, J.P., 1998. Overview of Applications of Ultrasonics in the Pulp and Paper Industry, Proceedings of IEEE International Ultrasonics SymposiumProceedings, 809-815.

Ingede Test Metodu 1, 2007. Optik Özelliklerin Ölçümü için Mürekkebi Giderilmiş Hamurdan Test Kâğıdı Hazırlama, Uluslararası Mürekkep Giderme Sanayi Kurumu verileri.

Ingede Test Metodu 2, 2007. Hamurun Optik Özelliklerinin Ölçümü ve Mürekkep Gidermedeki Süzüntü İşlemleri, Uluslararası Mürekkep Giderme Sanayi Kurumu verileri.

Ingede Test Metodu 11, 2007. Bask1lı Ürünün Geri Dönüşülebilirliği, Uluslararası Mürekkep Giderme Sanayi Kurumu verileri.

İmamoğlu, S., 2002. Atık Kâğıt Hamurlarının Formamaidin Sülfinik Asit (FAS) ile Ağartılması. Doktora Tezi, İstanbul Üniversitesi Fen Bilimleri Enstitüsü, İstanbul.

Karahan, S., 2012. Ultrasonik Enerji ve Enzim Kullanımının Lazer Baskılı Ofis Kâğıtlarından Yüzdürme Esaslı Mürekkep Giderme İşlemi Üzerine Etkileri. Doktora Tezi, Kahramanmaraş Sütçü İmam Üniversitesi Fen Bilimleri Enstitüsü, Kahramanmaraş.
Karahan, S., 2017a. Kâğıdın Optik Özellikler Üzerine Mürekkep Giderme İşlemi ile Farklı Uygulamaların Etkileri. Düzce Üniversitesi Bilim ve Teknoloji Dergisi, 5 (1), 146-160.

Karahan, S., 2017b. Mürekkep Giderme İşleminin Ofis Kâğıtları Üzerindeki Fiziksel Direnç Özellikleri Üzerine Etkisi. Düzce Üniversitesi Bilim ve Teknoloji Dergisi, 5 (1), 76-83.

Karahan, S., 2017c. Atık Ofis Kâğıtları Üzerinde Yapılan Mürekkep Giderme İşleminin Hamur Verimi ve Atık Çamur Üzerine Etkileri. Düzce Üniversitesi Bilim ve Teknoloji Dergisi, 5 (1), 67-75.

Karahan, S. ve Karademir, A., 2019. Mürekkep Giderme İşleminin Farklı Atık Kâğıtlar Üzerindeki Etkisi. Düzce Üniversitesi Bilim ve Teknoloji Dergisi, 7 (1), 15-24.

Karahan, S., Karademir, A. ve Güvendi, E., 2015a. Ofis Kâğıltarı Üzerindeki Mürekkep Giderme İşleminin Taramalı Elektron Mikroskobu ile Analizi. Düzce Üniversitesi Bilim ve Teknoloji Dergisi, 3 (1), 299-314.

Karahan, S., Karademir, A. ve Güvendi, E., $2015 b$. Mürekkep Giderme İşleminin Lazer Baskılı Ofis Kâğıtlarındaki Organik ve Anorganik Madde Miktarları Üzerine Etkileri. Düzce Üniversitesi Bilim ve Teknoloji Dergisi, 3 (1), 241-250.

Karademir, A., Akgül, M. ve Tutuş, A., 2002a. Kâğıt Endüstrisinde Enzim Kullanımına Genel Bir Bakış, Enzimlerin Kabuk Soyma, Liflerin Modifikasyonu, Çözünebilir Kâğıt Hamuru ve Selüloz Üretiminde Kullanımı. KSU Fen ve Mühendislik Dergisi, 5, 61-71.

Karademir, A., İmamoğlu, S. ve Tutuş, A., 2002b. Situation of paper based waste in Turkey. ISWA International Congress, 419-426.

Kenealy, W., Buschle-Diller, G., and Ren, X., 2006. Enzymatic Modification of Fibers for Textile and Forest Products Industries. Modified Fibers with Medical and Specialty Applications, 191208.

Kıran, Ö.E., Çömlekçioğlu, U. ve Dostbil N., 2006. Bazı Mikrobiyal Enzimler ve Endüstrideki Kullanım Alanları. KSU Fen ve Mühendislik Dergisi, 9, 12-19.

Peşman, E., 2010. Atık Gazete ve Magazin Kâğıtlarının Mürekkep Uzaklaştırma ve Ağartma Özelliklerinin Belirlenmesi. Doktora Tezi, Karadeniz Teknik Üniversitesi Fen Bilimleri Enstitüsü. Trabzon.

Skals, P., Krabek, A., Nielsen, P. ve Wenzel, H., 2008. Environmental Assesment of Enzyme Assisted 
Processig in Pulp and Paper Industry. Int LCA Case Studies, 13 (2), 124-132.

Tatsumi, D., Higashihara, T., Kawamura, S. ve Matsumoto, T., 2000. Ultrasonic Treatment to Improve the Quality of Recycled Pulp Fiber. Journal of Wood Science, 46 (5), 405-409.
Yılgör, N., 2010. Mürekkep Giderme Sürecinde Enzimlerin Kullanılması. Orman Fakültesi Dergisi, İstanbul Üniversitesi, 60 (1), 73-75.

Yilgör, N., Cameron, J., Velpumadugu, A. ve Kumar, K., 2009. Enzymatic Deinking of Inkjet Printed Papers, Pulping \& Environmental Conference, $1-14$. 